See discussions, stats, and author profiles for this publication at: https://www.researchgate.net/publication/322796348

Changes in European instruments as a reflection of a shift in legal philosophies relating to community sanctions and measures

Article in European Journal on Criminal Policy and Research · January 2018 DOI: $10.1007 /$ s10610-018-9369-2

1 author:

Xue Yang

Ghent University

1 PUBLICATION 0 CITATIONS

SEE PROFILE 


\title{
Changes in European instruments as a reflection of a shift in legal philosophies relating to community sanctions and measures
}

\author{
Xue Yang ${ }^{1}$ (D)
}

(C) Springer Science+Business Media B.V., part of Springer Nature 2018

\begin{abstract}
The number of persons under community sanctions and measures in the criminal justice system have grown rapidly in many European countries. In response to this phenomenon, the Council of Europe has issued several recommendations on community sanctions and measures in recent decades. The European Union has also published two framework decisions concerning community sanctions and measures that are legally binding on its member states. This article examines the shifts of the general legal philosophies of European instruments on community sanctions and measures, through a review of the subtle changes in the rhetoric of these. Results show that community sanctions and measures are increasingly promoted because of their inherent value, rather than simply because they provide the means to reduce the use of imprisonment. The European instruments assert interdependence between the two objectives of offender rehabilitation and public protection, consider the indicators related to both as the criteria for effective supervision, and understand community sanctions and measures as being not only efficiency oriented but also based on Europe's human rights framework. However, a particular concern — risk management of dangerous offenders - leads to looser interpretations of some principles of human rights. To retain the European image of resisting punitiveness, this problem can be addressed by firmer and stricter interpretation of these principles.
\end{abstract}

Keywords Community sanctions and measures $\cdot$ European instruments $\cdot$ Legal philosophies

Xue Yang

Xue.Yang@UGent.be

1 Institute For International Research on Criminal Policy, Faculty of Law and Criminology, Ghent University, Ghent, Belgium 


\section{Introduction}

Throughout Europe, there are various definitions, forms, and configurations of community sanctions. However, there are also some common trends. In many European countries, the number of persons under community sanctions and measures continues to increase. Furthermore, the range of these sanctions is broadening, and their intensity is increasing (Graebsch and Burkhardt 2014; McNeill 2013; McNeill and Beyens 2013; Stefani 2016). The SPACE I and SPACE II Reports present the annual penal statistics of the Council of Europe (CoE) member states. These reports show that, in many European countries in 2012, more people were under the supervision or care of probationary services than in prison (Aebi and Chopin 2013; Aebi and Delgrande 2013). Some scholars label this phenomenon 'mass supervision' (McNeill 2013; McNeill and Beyens 2013; Phelps 2013).

Mass supervision reflects the commitment of European instruments to increasingly impose community sanctions and measures(CSMs). Recommendation No. R(92)16 'On the European Rules on Community Sanctions and Measures' has very recently been replaced and updated by Recommendation CM/Rec(2017)3 'On the European Rules on Community Sanctions and Measures' issued by the $\mathrm{CoE}$. The $\mathrm{CoE}$ has also published several other recommendations on CSMs. Albeit not legally binding, these recommendations can greatly influence member states. Two measures that are binding for European Union (EU) member states, through transposition into national law, are(1) Council Framework Decision 2008/947/JHA of 27 November 2008 'On the Application of the Principle of Mutual Recognition to Judgments and Probation Decisions with a View to the Supervision of Probation Measures and Alternative Sanctions'; and (2) Council Framework Decision 2009/829/JHA of 23 October 2009 'On the Application of the Principle of Mutual Recognition to Decisions on Supervision Measures as an Alternative to Provisional Detention'.

This article reviews the penal policy of CSMs under these European instruments, referring also to the related literature. There have been subtle changes in the rhetoric of these European instruments. These reflect shifts and reconciliations in CSMs objectives and effectiveness criteria. This article examines the general legal philosophies of European instruments on how to resist punitiveness but maintain the punitive character of CSMs, how to balance protecting society and rehabilitating offenders, how to correlate short-term offender compliance with the long-term aim of desistance, and how to apply human rights standards with CSMs.

\section{The objectives of community sanctions under European instruments}

\section{The objectives under the CoE's recommendations}

\section{Reducing the use of imprisonment}

The CoE has issued several recommendations on reducing imprisonment and promoting CSMs. These recommendations support a reductionist policy. According to Rutherford (1984, pp. 145-147), there are two general conditions of a reductionist policy: first, key decision-makers share profound scepticism about the benefits of imprisonment; second, they have profound intolerance of overcrowding in prisons.

The recommendations convey doubts about the effectiveness of imprisonment. They also commit to tackle prison population inflation. Resolution (76)10 'On Certain Alternative Penal 
Measures to Imprisonment' recognises that prison sentences have many drawbacks. It also states that alternative sentences can 'serve the object of rehabilitating offenders and are less costly than imprisonment'. ${ }^{1}$ Subsequent recommendations on community sanctions and measures $^{2}$, including reinforce Resolution (76)10 on the negative effects of imprisonment and the potential for CSMs to avoid these problems. Recommendation No. R(99)22 'Concerning Prison Overcrowding and Prison Population Inflation' regards the deprivation of liberty as a last resort. It states that 'prison overcrowding and prison population growth represent a major challenge to prison administrations and the criminal justice system as a whole, both in terms of human rights and of the efficient management of penal institutions' ${ }^{3}$ Recommendation Rec(2006)2 'On the European Prison Rules' reiterates that liberty should be deprived only as a last resort. It also stipulates that minimum accommodation requirements must not be breached by prison overcrowding. ${ }^{4}$

The recommendations use both 'front-door strategies' and 'back-door strategies' to reduce the prison population. The front-door strategies involve imprisoning fewer people, while the back-door strategies focus on shortening prison sentences on conviction (De Vos et al. 2014; Snacken 2006; Tonry 2006). Resolution (76)10 aims to expand alternatives to imprisonment. It calls on member states to develop both existing and new alternatives. Besides CSMs, it also requires member states to use fines 'as sanctions on a broad basis,, and semi-detention 'as a milder form of punishment than total imprisonment'. ${ }^{6}$ However, Recommendation No. $\mathrm{R}(99) 22$ omits fines from its list of sanctions to solve prison overcrowding. ${ }^{7}$ This recommendation requires member states to provide an appropriate array of CSMs, possibly graded in terms of relative severity. ${ }^{8}$ It also requires member states to combine custodial and noncustodial sanctions and measures $;{ }^{9}$ and use specific approaches in enforcing custodial sentences. These include, for example semi-liberty, open regimes, prison leave, or extramural placements. ${ }^{10}$

The CoE's recommendations require wide use of CSMs. In replacing Recommendation Rec (2000)22, Recommendation CM/Rec (2017)3 restates its key principles on this topic. The new recommendation expects member states to provide for non-custodial sanctions or measures instead of imprisonment as the appropriate response for certain offences in national laws. ${ }^{11}$ Member states are also expected to review and reduce formal provisions preventing CSMs use for serious and repeat offenders. ${ }^{12}$ Many European jurisdictions have responded by broadening the scope of offenders eligible for CSM.

Snacken (2006) maintains that 'imprisonment as a last resort' is the guiding principle in European penal policies. Snacken's (2006, p. 145) spatial comparative study shows that

\footnotetext{
${ }_{1}^{1}$ Preamble, Resolution (76)10.

2 These recommendations include Recommendation No. R (92) 16, Recommendation Rec(2003)22 'On Conditional Release (Parole)', Recommendation CM/Rec(2010)1, and Recommendation CM/Rec(2017)3.

${ }^{3}$ Preamble and Rule 1, Recommendation No. R(99)22.

${ }^{4}$ Preamble and Rule 18.4, Recommendation Rec(2006)2.

${ }^{5}$ Rule 2b, Resolution (76)10.

${ }^{6}$ Rule 3d, Resolution (76)10.

${ }^{7}$ Recommendation No. R(99)22 should not devalue the role of fines in reducing prison population. In Scandinavia and Germany, fines serves as a dominant alternative, and contributes effectively to low short-term imprisonment rates (Dünkel 2017; Lappi-Seppala 2008).

${ }^{8}$ Rules 3, 14, and 15, Recommendation No. R(99)22.

${ }^{9}$ Rule 17 , Recommendation No. R(99)22.

${ }^{10}$ Rule 9, Recommendation No. R(99)22.

${ }^{11}$ Rule 2, Recommendation Rec (2000)22; Rule 18, Recommendation CM/Rec (2017)3.

${ }^{12}$ Rule 3, Recommendation Rec (2000)22; Rule 19, Recommendation CM/Rec (2017)3.
} 
European prison populations are modest and the level of punitiveness is low compared with the dramatical increase in the US prison population in the US over the last 20 years. ${ }^{13}$ However, Aebi et al.'s (2015) temporal comparative study finds that the increase of CSMs in Europe has no visible effect on prison population rates from 1991 to 2010 in European countries.

\section{Balancing protecting society and rehabilitating offenders}

Under Resolution (76)10, CSMs are promoted because they overcome the problems of imprisonment. CSMs are 'only one of the items in a more comprehensive toolbox' for alternatives to imprisonment (Martufi and Slingeneyer 2017, p. 8). Under subsequent recommendations, the 'inherent value' of CSMs beyond a simple means to reduce imprisonment has been increasingly recognised (van Zyl Smit et al. 2015, p. 14).

Under Recommendation No. R(92)16, pursuing an alternative to imprisonment does not justify recourse to any kind of sanction or measure: ${ }^{14}$

'the application of community sanctions and measures must maintain a necessary and desirable balance between, on the one hand, the need to protect society both in the sense of the maintenance of legal order as well as the application of norms providing for reparation for the harm caused to victims, and, on the other hand, the essential recognition of the needs of the offender having regard to his social adjustment'. ${ }^{15}$

'the implementation of penal sanctions within the community itself rather than through a process of isolation from it may well offer in the long term better protection for society including, of course, the safeguarding of the interests of the victim or victims'. ${ }^{16}$

The following European instruments on community sanctions and measures also aim to balance protecting society with rehabilitating offenders, asserting that social inclusion can enhance community safety.

Recommendation $\operatorname{Rec}(2003) 22$ stipulates that:

'conditional release should aim at assisting prisoners to make a transition from life in prison to a law-abiding life in the community through post-release conditions and supervision that promote this end and contribute to public safety and the reduction of crime in the community'. ${ }^{17}$

The more recent Recommendation CM/Rec(2010)1 provides that:

'probation agencies shall aim to reduce reoffending by establishing positive relationships with offenders in order to supervise (including control where necessary), guide and assist them and to promote their successful social inclusion; probation thus contributes to community safety and the fair administration of justice'. ${ }^{18}$

\footnotetext{
13 The imprisonment rates have declined recently. According to Dünkel (2017), it is somewhat due to decriminalising minor property offences and declining in registered crimes and convictions in Eastern European countries, and partly because of the decreasing seriousness of registered crimes in the Netherlands, Germany and Spain.

${ }^{14}$ Preamble b, Recommendation No. R(92)16.

${ }^{15}$ Preamble a, Recommendation No. R(92)16.

${ }^{16}$ Preamble c, Recommendation No. R(92)16.

${ }^{17}$ Rule 3 of the Recommendation Rec(2003)22.

${ }^{18}$ Rule 1, Recommendation CM/Rec(2010)1.
} 
The Commentary to Recommendation $\mathrm{CM} / \operatorname{Rec}(2017) 3$ reiterates the value of CSMs for suspects, offenders and the community. ${ }^{19}$

As Snacken and McNeill (2012, p. 562) observe, 'it seems that there is an emerging consensus at European level that, whereas all penal sanctions, including deprivation of liberty, aim at reducing reoffending and protecting victims and the general public, a particular characteristic of probation measures is their emphasis on working with offenders in the community and fostering their social rehabilitation and inclusion'.

\section{The Objectives under Council of the EU framework decisions: facilitating CSMs for foreigners}

Council Framework Decisions 2008/947/JHA and 2009/829/JHA reinforces the CoE's recommendations regarding the objectives of CSMs. These decisions also aim to facilitate the social rehabilitation of sentenced persons, improve protection of victims and the general public and ensure the due course of justice. ${ }^{20}$ They also seek to facilitate applying suitable probation measures and alternative sanctions for offenders who live outside the state of trial or conviction. $^{21}$

As the EU develops its competence in 'freedom, security and justice, ${ }^{22}$, it grows increasingly dominant in encouraging the free movement of criminal justice (Baker 2013). Judicial cooperation in criminal matters is fundamentally founded on mutual recognition (Vermeulen and De Bondt 2014). The two aforementioned Council framework decisions are both based on this core principle. They aim to promote effective and efficient judicial cooperation between member states regarding community sanctions and measures.

States are more likely to impose custodial sanctions and measures on foreigners than on nationals. This relfects the strong possibility of noncompliance with community sanctions and measures among foreign suspects and offenders, due to the risk of absconding and language problems, for example (De Wree et al. 2009; Morgenstern 2009; Ruggiero et al. 1998).

The mutual recognition of judgements and decisions enables foreign suspects or offenders, regardless of where they are sentenced, to serve community sentences in the EU member state in which they reside. This policy potentially increases the application of non-custodial sanctions and measures to foreigners, though neither Council framework decisions directly calls for this. Like the recent recommendations issued by the $\mathrm{CoE}$, the two Council framework decisions are designed to increase CSMs use on their own merits, rather than simply to replace custodial sanctions and measures (van Zyl Smit et al. 2015, p. 17).

Mutual recognition of judgements and decisions on CSMs is understood to benefit both offender reintegration and crime control. Transferring offenders to their home states may facilitate their reintegration. This is because it avoids linguistic and cultural barriers, as well as provides better access to services and social ties (De Wree et al. 2009; Morgenstern 2009). Meanwhile, to ensure effective crime control, transferring sentenced persons at least partly upholds the issuing states' sentences. The framework decisions generally prohibit converting imprisonment into an alternative sentence (De Wree et al. 2009). Unless one of the grounds for refusal in the framework decisions applies, executing states should recognise issuing states'

\footnotetext{
${ }_{19}$ Scope and Purpose of the Commentary to Recommendation CM/Rec(2017)3.

${ }^{20}$ Article 1 (1), Council Framework Decision 2008/947/JHA; Article 2(1), Council Framework Decision 2009/829/JHA.

${ }^{21}$ Id.

${ }^{22}$ Article 1, Treaty of Amsterdam amending the Treaty on European Union.
} 
judgements and decisions. ${ }^{23}$ Executing states must also enforce judgements and decisions exactly as issued except where the nature or duration of the sanctions or measures are incompatible with domestic law. ${ }^{24}$ Where sanctions and measures are adapted, they must correspond as far as possible to those imposed in the issuing state ${ }^{25}$. When the duration of the measure in the issuing state exceeds the maximum duration under domestic law, the adapted period shall not be below the maximum duration provided for equivalent offences under domestic law ${ }^{26}$. It means that the executing state must fully exploit its domestic sentencing framework (Morgenstern and Larrauri 2013).

\section{The effectiveness criteria of community sanctions and measures}

\section{The punitive shift}

The punitive character of CSMs is uncertain when they are viewed as measures of clemency. Snacken (2010) states that punitiveness is 'a complex, not always clearly defined concept'. Robinson (2016) and Snacken (2010) find that the prevalence of rehabilitative ideals, imprisonment rates and prison conditions are often referred to as the parameters of punitiveness. CSMs are traditionally the key domain for rehabilitative interventions, and enjoy the status of an alternative to imprisonment (Robinson 2008, 2016). Therefore, the expansion of CSMs seems to run counter to the trend of punitiveness. The public's perception of CSMs has been shaped by this traditional understanding of punitiveness (Beyens 2016; Morris and Tonry 1991; Robinson 2016; Robinson and McNeill 2015). As Morris and Tonry (1991) observe, in the minds of most, CSMs are seen as lenient treatment or a 'let off'.

In the post-1990s European instruments on CSMs, two key aspects have served to change public perceptions of impunity. These are the broadened scope of criminals eligible for such sentences and the increasing emphasis on public protection. The punitive weights have been increasing, as reflected by various demanding conditions and obligations attached to CSMs. There has also been increasing use of some pure controlling methods to facilitate offender supervision, such as electronic monitoring.

\section{The shift in focus of effectiveness criteria}

Under Resolution (76)10, the utilitarian basis for using alternatives to imprisonment is their greater cost effectiveness. ${ }^{27}$ In this sense, two approaches best accommodate cost reduction: first, ordering payment of a fine without attaching conditions or obligations; second, imposing collective CSMs, such as suspended sentences and early release, with no conditions other than avoiding reoffending. Under Recommendation No. R(92)16, the effectiveness criteria for CSMs shifted from cost effectiveness to public protection and offender rehabilitation. At that point, effective control of offenders become a crucial indicator. Under Recommendation No.

\footnotetext{
$\overline{23}$ Article 11, Council Framework Decision 2008/947/JHA.

${ }^{24}$ Article 9 (1), Council Framework Decision 2008/947/JHA.

${ }^{25}$ Id.

${ }^{26}$ Article 9 (2) of the Council Framework Decision 2008/947/JHA.

${ }^{27}$ Preamble of the Resolution (76)10.
} 
$\mathrm{R}(99) 22$ and Recommendation Rec2000(22), the credibility of CSMs depends on their effective supervision and control of offenders. ${ }^{28}$

Recommendation No. R(92)16 particularly emphasises individualised CSMs programmes. It requires the implementation of community sanctions and measures to be individually adapted to the particular circumstances of each case. ${ }^{29}$ These stipulations are retained in Recommendation $\mathrm{CM} / \operatorname{Rec}(2017) 3 .^{30}$

Collective measures do not usually involve much control, beyond the single condition of avoiding reoffending. They mostly result in forms of unconditional release. By contrast, individualised programmes usually attach different conditions and obligations to different offenders according to their circumstances. This allows close oversight of their conduct in the community (Martufi and Slingeneyer 2017, p. 10; van Zyl Smit et al. 2015, p. 16).

Recommendation No. R(99)22 and Recommendation Rec(2003)22 also stress the individualisation of sanctions, deemed by the former to be part of a 'coherent and rational criminal policy'. 31

'The development of measures should be promoted which reduce the actual length of the sentence served, by giving preference to individualised measures, such as conditional release (parole), over collective measures for the management of prison overcrowding (amnesties, collective pardons)', 32

Recommendation $\operatorname{Rec}(2003) 22$ defines conditional release as 'the early release of sentenced prisoners under individualised post-release conditions' ${ }^{33}$ According to van Zyl Smit et al. (2015, p. 16), 'by its narrow definition of conditional, the recommendation may inadvertently encourage the setting of conditions'.

\section{The construction of compliance}

For offenders subject to individualised CSMs programmes, their effective supervision and control are closely linked with the offenders' subsequent compliance with the criminal law. As Mair and Canton (2007, p. 270) identify, CSMs are distinguished from imprisonment and other punishments, as their objectives can only be achieved if offenders actively comply with the conditions and obligations; if offenders do not comply, 'an unenforced community penalty is indistinguishable from impunity'.

It is widely recognised that compliance is an elastic concept with different dimensions. Bottoms (2001, p. 89) proposes two dimensions of compliance with community sanctions. First, 'short-term requirement compliance' concerns the specific legal requirements of CSMs. Second, 'long-term legal compliance' means no reoffending. Robinson (2013) deems longterm legal compliance as equivalent to desistance. Within Bottoms' short-term category, Robinson (2013, p. 28); Robinson and McNeill (2008) distinguish between behaviour that technically conforms to rules and that which reflects genuine engagement with a particular sanction and its purposes. The former only reflects the behavioural dimension of compliance, labelled formal compliance. Conversely, the latter adds the attitudinal dimension, and so is

\footnotetext{
$\overline{28}$ Rule 22, Recommendation No. R(99)22; Rule 15, Recommendation Rec2000(22).

${ }^{29}$ Rule 70 and 71, Recommendation No. R(92)16.

${ }^{30}$ Rule 32 and 33, Recommendation CM/Rec (2017) 3.

${ }^{31}$ Preamble, Recommendation No. R(99)22.

${ }^{32}$ Rule 23, Recommendation No. R(99)22.

${ }^{33}$ Rule 1, Recommendation $\operatorname{Rec}(2003) 22$.
} 
regarded as substantive compliance. Robinson and McNeill (2008) formulated a dynamic model of compliance. They advocate supervisors moving beyond formal compliance into substantive compliance. They also note that, the signs of substantive compliance increase the likelihood of achieving long-term compliance. According to Robinson (2013, pp. 40-41), the definition of compliance is shaped by how the purposes of CSMs are understood. Concerned only with their punitive character or managerial justice, we would prioritise the easily auditable formal compliance. Conversely, if we emphasise rehabilitation or managing risk and long-term public protection, we need to value both formal and substantive compliance. Bottoms (2001) finds that long-term compliance could be achieved through cognitive-behavioural programmes. Such programmes seek to alter an offender's ways of thinking (disposition). This is linked, in a two-way process, to altered behavioural routines. Such changes seem particularly likely to have lasting effects (Bottoms 2001, p. 94). During the 1980s, the cognitive-behavioural theory was applied to explain offender behaviours. This led to the development of the risk-need-responsivity model of rehabilitation programmes. These programmes became a main source of momentum for reviving rehabilitative optimism (McGuire 2004; Robinson and Crow 2009).

Changes over time in the CoE's recommendations on implementing CSMs reflect shifting concerns on the different compliance dimensions. Recommendation No. R(92)16 is designed to establish common CSMs ensure standards to provide just and effective application. ${ }^{34}$ Concerning the mechanisms of compliance, the recommendation's Chapter X merely provides the procedure for dealing with non-compliance or inadequate compliance. ${ }^{35}$ Recommendation No. R(92)16 does not address how to develop comprehensive strategies for long-term desistance. Compared with Recommendation No. R(92)16, Recommendation Rec2000(22) subtly changes the rhetoric by committing to achieve more effective use of CSMs. ${ }^{36}$ According to the European Committee on Crime Problems (2014), Recommendation Rec2000(22) aims to interpret and improve the implementation of Recommendation No. R(92)16. As Morgenstern (2016, p. 2) states, this reflects a subtle shift of emphasis from justice to effectiveness. For guidance on setting up effective programmes and intervention, Recommendation Rec(2000)22 directly refers to the risk-need-responsivity model. This model provides the criteria to guide offenders' allocation to specific programmes and interventions. ${ }^{37}$ The recommendation also refers to cognitive behavioural methods as widely accepted recent research findings to develop programmes and interventions for offenders who have relapsed into serious crime or are likely to do so. ${ }^{38}$

Subsequent recommendations on CSMs all underline the importance of adopting strategies based on established theory to improve effectiveness. Recommendation No. R(99)22 particularly advocates the development and use of reliable risk-prediction and risk assessment techniques, as well as supervision strategies. ${ }^{39}$ Recommendation CM/Rec(2010)1 provides guidance on the establishment and proper functioning of probation agencies. ${ }^{40}$ Its commentary stresses that supervision should target rehabilitation and desistance ${ }^{41}$. To achieve the latter, it

\footnotetext{
${ }^{34}$ Preamble, Recommendation No. R(92)16.

${ }^{35}$ Rule 76 to Rule 88, Recommendation No. R(92)16.

${ }^{36}$ Preamble, Recommendation Rec2000(22).

${ }^{37}$ Rule 22, Recommendation $\operatorname{Rec}(2000) 22$.

${ }^{38}$ Rule 23, Recommendation $\operatorname{Rec}(2000) 22$.

${ }^{39}$ Rule 22, Recommendation No. R(99)22.

${ }^{40}$ Scope and Application of Recommendation CM/Rec (2010)1.

${ }^{41}$ Rule 76 , Commentary to Recommendation $\mathrm{CM} / \operatorname{Rec}(2010) 1$.
} 
endorses the good lives model of offender rehabilitation. ${ }^{42}$ The recommendation seeks to establish a positive and professional relationship between the probation officer and offenders. This should enable offenders to play an active role in the supervision process. ${ }^{43}$ When pure controlling measures like electronic monitoring form part of probation supervision, this should facilitate the effectiveness of rehabilitative programmes. ${ }^{44}$ Recommendation CM/Rec(2014)4 'On Electronic Monitoring' clarifies the limited effectiveness of formal compliance. As a pure controlling measure, electronic monitoring can only ensure supervision and reduce crime while in force. To seek longer term desistance from crime, it should be combined with other professional interventions and supportive measures targeting offenders' social reintegration. ${ }^{45}$ Even for dangerous offenders, Recommendation CM/Rec(2014)3 'Concerning Dangerous Offenders' requires their risk management to have the long-term aim of safe reintegration into the community. ${ }^{46}$

As the combination and entrenchment of Recommendation No. R(92)16 and Recommendation Rec 2000(22), Recommendation CM/Rec(2017)3 preserves the former's stipulations on noncompliance. ${ }^{47}$ Meanwhile, the Commentary to Recommendation CM/Rec(2017)3 reiterates the following provisions of Recommendation Rec 2000(22). In determining any CSMs conditions or obligations, the individual's needs and risks must be considered to support desistance. The principle is applied even for measures involving high levels of surveillance or control. $^{48}$ Like Recommendation CM/Rec(2010)1, the new recommendation recognises the effectiveness of sound professional relationships in engendering attitudinal and behavioural changes. Likewise, it also recommends a package of sanctions and measures to accommodate the different dimensions of compliance. ${ }^{49}$ The list of effectiveness criteria in the Commentary to Recommendation $\mathrm{CM} / \operatorname{Rec}(2017) 3$ includes most of the targets in Recommendation No. $\mathrm{R}(92) 16$. These include fulfilling public expectations of law and policy, reducing imprisonment, meeting offenders' offence-related needs, and improving cost-effectiveness. ${ }^{50}$ Yet, the top three listed criteria are the reconviction rate, the process of desistance, and formal desistance. ${ }^{51}$ The recommendation identifies the reconviction rate as 'one significant measure of effectiveness'. ${ }^{52}$ However, it does not recommend absolute (low) targets for the reconviction rate to prove the effects of CSMs. Instead, it suggests the comparative assessment of effectiveness. The effect of a particular CSM 'should be carefully compared with the reconvictions of comparable offenders receiving imprisonment as well as other sanctions and measures'. 53

There are, thus, strong signs of two recent trends in the recommendations. First, they increasingly favour both the behavioural and attitudinal dimensions of compliance. Second, they place high value on desistance. Effective implementation methods are being stimulated by the research findings of 'what works', which primarily originate in Canada, the USA, and

\footnotetext{
42 Rules 66 and 67, Commentary to Recommendation CM/Rec(2010)1.

${ }^{43}$ Rule 1, Recommendation CM/Rec(2010)1.

${ }^{44}$ Rule 57, Commentary to Recommendation CM/Rec(2010)1.

${ }^{45}$ Rule 8, Recommendation CM/Rec(2014)4.

${ }^{46}$ Rule 6, Recommendation CM/Rec(2014)3.

${ }^{47}$ Rule 62 to Rule 72, Recommendation CM/Rec(2017)3.

${ }^{48}$ Rule 23, Recommendation Rec 2000(22); Rule 37, Commentary to Recommendation CM/Rec(2017)3.

${ }^{49}$ Rule 1, Recommendation CM/Rec(2010)1; Rule 31, Commentary to Recommendation CM/Rec(2017)3.

${ }^{50}$ Rule 90, Recommendation No. R(92)16.

${ }^{51}$ Rule 99, Commentary to Recommendation $\mathrm{CM} / \operatorname{Rec}(2017) 3$.

52 Id.

${ }^{53}$ Id.
} 
England and Wales. ${ }^{54}$ The Commentary to Recommendation CM/Rec(2010)1 states that 'countries can and should use evidence from other countries to develop their own practices'. 55 However, the recommended cognitive behavioural methods are questioned by scholars from countries not schooled in Anglo-Saxon traditions (Herzog-Evans 2013; van Zyl Smit et al. 2015). With a subtle change from the Commentary to Recommendation $C M / \operatorname{Rec}(2010) 1$, the Commentary to Recommendation CM/Rec(2017)3 states that 'Practices that have proved to be successful in one country may be a promising idea to introduce elsewhere' ${ }^{56}$ The new Commentary uses 'may' rather than 'can and should'. However, it lists no promising ideas other than cognitive behavioural methods.

\section{Human rights standards in the context of community sanctions and measures}

\section{The rise of human rights issues}

McNeill (2013, p. 5) contends that, when the punitive character of CSMs was uncertain, it resulted in 'the slower progress of human rights discourses in the field of community sanctions and measures than in relation to imprisonment'. Those subjected to community sanctions and measures were regarded as recipients of mercy. Therefore, they were deprived of the moral basis for legitimate claims to any entitlements to CSMs and to fair treatment in the punishment's execution (McNeill 2013, p. 6). To reinforce UN Resolution 663 C (XXIV) 'Standard Minimum Rules for the Treatment of Prisoners', the CoE issued Resolution (73) 5 'European Standard Minimum Rules for the Treatment of Prisoners'. Subsequently, the CoE's Committee of Ministers adopted Recommendation No. R (87) 3 'On European Prison Rules' (Coyle 2005). This renews emphasis on the precepts of human dignity and the commitment of prison administrations to humane and positive treatment. In contrast, Resolution (76)10 gives alternatives to imprisonment a semblance of beneficence, and completely overlooks human rights problems.

In the 1990s, the intrusive dimensions of CSMs attracted increasing attention. As Snacken (2006, p. 160) observes, though CSMs are typically less interfering than imprisonment, they nonetheless restrict freedom of movement. They may also hamper the enjoyment of other rights and freedoms. From the offender's perspective, particularly demanding forms of CSMs are not always more lenient and less intrusive than imprisonment. Some CSMs, especially those imposed on high-risk offenders, are very intensive and feature many punitive aspects. To control high-risk offenders, Recommendation Rec (2000)22 even allows the possibility of indeterminate CSMs. This conflicts with the earlier Recommendation No. R(92)16: 'no community sanction or measure shall be of indeterminate duration'. ${ }^{57}$ Recommendation Rec (2000)22 stipulates that:

'exceptionally, an indeterminate community sanction or measure may be imposed on offenders who, by reason of a serious prior or current offence in combination with a

\footnotetext{
${ }_{54}$ Rule 104, Commentary to Recommendation CM/Rec(2010)1.

55 Id.

${ }^{56}$ Rule 98, Commentary to Recommendation CM/Rec(2017)3.

${ }^{57}$ Rule 5, Recommendation No. R(92)16.
} 
specific personal characteristic manifestly pose a continuing grave threat to life, health or safety in the community, 58

Recommendation Rec (2017)3 continues to allow indeterminate community sanctions or measures. ${ }^{59}$ Durnescu et al. (2013); Graebsch and Burkhardt (2014) find that some offenders under community sanctions perceive those sanctions to be excessively punitive. Consequently, they can be anxious about the intrusion into their private life.

Accordingly, on CSMs, the CoE's instruments require member states to refer to other European human rights instruments and standards. Recommendation No. R(92)16 offers basic criteria for combining the creation and use of CSMs with guarantees against curtailing offenders' fundamental human rights. ${ }^{60}$ Chapter 3 of Recommendation No. R(92)16, titled 'respect for fundamental rights', prescribes that:

'no community sanction or measure restricting the civil or political rights of an offender shall be created or imposed if it is contrary to the norms accepted by the international community concerning human rights and fundamental freedoms'. ${ }^{61}$

Recommendation Rec (2000)22 states that:

'the recourse to, and the implementation of, community sanctions and measures should always be guided by respect for fundamental legal safeguards as enshrined in the European Convention on Human Rights, and by the principles laid down in the European Rules'. ${ }^{2}$

Recommendation $\operatorname{Rec}(2017) 3$ preserves and strengthens the human rights protections under these two earlier recommendations. ${ }^{63}$ Other $\mathrm{CoE}$ instruments on CSMs, ${ }^{64}$ also set human rights principles as basic values, and refer to other European human rights instruments and standards. ${ }^{65}$

'Respect for human rights' is among the EU's baseline values. In the context of criminal law, the mutual recognition principle of EU legal instruments is based on mutual trust between member states' criminal justice authorities. This is derived from the consensus that 'all can be relied upon to respect fundamental rights and the other fundamental principles of Union law' (Baker 2013, p. 90). Council Framework Decisions 2008/947/JHA and 2009/829/JHA also endorse respect for fundamental rights and legal principles, as enshrined in Article 6 of the Treaty on European Union. ${ }^{66}$

Under both the European Convention on Human Rights (ECHR) and the Charter of Fundamental Rights of the EU (CFR), 'no one shall be subjected to torture or to inhuman or degrading treatment or punishment' ${ }^{67}$ The ECHR labels this right as non-derogative

\footnotetext{
58 Appendix 1, Recommendation Rec (2000)22.

${ }^{59}$ Rule 23, Recommendation Rec (2017)3.

${ }^{60}$ Preamble b, Recommendation No. R(92)16.

${ }^{61}$ Rule 21, Recommendation No. R(92)16.

${ }^{62}$ Preamble, Recommendation Rec (2000)22.

${ }^{63}$ Preamble b and Rule 4, Recommendation Rec(2017)3.

64 These instruments include Recommendation Rec(2003)22, Recommendation CM/Rec(2010)1, and Recommendation $\mathrm{CM} / \operatorname{Rec}(2014) 4$.

${ }^{65}$ Rule 36, Recommendation Rec(2003)22; Scope and Application, and Rule 2, Recommendation CM/ Rec(2010)1; Preamble, Recommendation CM/Rec(2014)4.

${ }^{66}$ Article 1(4), Framework Decision 2008/947/JHA; Article 5, Framework Decision 2009/829/JHA.

${ }^{67}$ Article 3, European Convention on Human Rights; Article 4, Charter of Fundamental Rights of the European Union.
} 
(Ashworth and Horder 2013). According to Morgenstern and Larrauri (2013); van Zyl Smit and Ashworth (2004), 'inhuman or degrading treatment or punishment' can be interpreted in one or both of two ways. One interpretation concerns the nature of the treatment or punishment. Particular type of punishment should be outlawed because of their intrinsically 'cruel and unusual' or 'inhuman and degrading' character. The other interpretation concerns, in this context, the intensity of community sanctions and measures. If the severity of a punishment is grossly disproportionate to the seriousness of the crime(s), that punishment is also inhuman and degrading'.

\section{Outlawing particular types of sanctions and measures}

Concerning the nature of CSMs, under Recommendation No. R(92)16,

'the nature of all community sanctions and measures and the manner of their implementation shall be in line with any internationally guaranteed human rights of the offender. The nature, content and methods of implementation of community sanctions and measures shall not jeopardise the privacy or the dignity of the offenders or their families, nor lead to their harassment. Nor shall self-respect, family relationships, links with the community and ability to function in society be jeopardised. Safeguards shall be adopted to protect the offender from insult and improper curiosity or publicity'. ${ }^{68}$

These rules are preserved in Recommendation CM/Rec(2017)3. ${ }^{69}$

The European Court of Human Rights (ECtHR) gives no clear guidance on what types of CSMs are considered torture or inhuman or degrading treatment and punishment. The court refrains from expressly listing prohibited acts (Long and Association for the Prevention of Torture 2002). The ECtHR believes that human rights protection standards should be interpreted with reference to present-day conditions. Also, as standards become increasingly high, great firmness is required in assessing what constitutes a breach of fundamental values (Long and Association for the Prevention of Torture 2002).

Although the ECtHR does not specify what forms of CSMs should be precluded, many scholars contend that certain CSMs may violate human rights by their very nature. To judge whether a particular CSM is inhuman or degrading, Morgenstern and Larrauri (2013); Snacken and McNeill (2012) suggest consulting the reports of the European Committee for the Prevention of Torture and Inhuman or Degrading Treatment or Punishment (CPT). It should be noted, though, that the CPT focuses on persons deprived of their liberty. The authors give the example of surgical castration in the Czech Republic, considered by the CPT to amount to degrading treatment. In its report to the Czech Government, the CPT cited the ethical problems of serious physical and mental harm inflicted on an offender. ${ }^{70}$ The ethical issues in using electronic monitoring, which manages risks through techno-correctional innovation, have received considerable academic attention. Some studies show that electronic monitoring may reinforce patterns of gender inequality, cause stigma and embarrassment for suspects or offenders, and place stress on members of their households (Holdsworth and Hucklesby 2014; Jones 2014; Nellis 2015). Recommendation CM/Rec(2014)4 sets basic principles on

\footnotetext{
${ }^{68}$ Rules 21 and 22, Recommendation No. R(92)16.

${ }^{69}$ Rule 8, Recommendation CM/Rec(2017)3.

${ }^{70}$ Article 44 of the Report to the Czech Government on the visit to the Czech Republic carried out by the CPT from 25 March to 2 April 2008 (CPT/Inf (2009) 8).
} 
ethical use of electronic monitoring. First, it emphasises that any decisions to implement electronic monitoring should consider each suspect's or offender's specific conditions and personal circumstances. Second, such monitoring should eschew inflicting intentional physical or mental harm or suffering on a suspect or offender. Third, undue intrusiveness into the private and family life of suspects, offenders, and other affected persons should be avoided. ${ }^{71}$

\section{The legality principle}

Concerning the intensity of community sanctions, the CFR sets clear legality and proportionality principles to limit such penalties. ${ }^{72}$ The legality principle promotes predictability in judging the legal consequences of one's actions. It also protects individuals against arbitrary political, prosecutorial, or judicial power, prohibiting punishment through restrospective application of substantive new crimes or increased punishments (Gallant 2009, pp. 20-21). Recommendation No. R(92)16 also prescribes the legality principle, making the credibility of CSMs dependent on clear rules of conduct. ${ }^{73}$

Recommendation No. R(92)16 requires clear and explicit legal provisions on the conditions and obligations of CSMs, and the consequences of non-observance. It also prohibits indeterminate CSMs. ${ }^{74}$ As van Zyl Smit (1993, p. 322) interprets, this requirement sets a clear limit on the sentence length, precluding sentences that, cumulatively, are unacceptably harsh. However, Recommendation Rec(2000)22 permits indeterminate CSMs in exceptional cases. If offenders must 'manifestly pose a continuing grave threat to life, health or safety in the community'. ${ }^{75}$ The subsequent Recommendation $\operatorname{Rec}(2003) 22$ also allows indeterminate conditional release 'when this is absolutely necessary for the protection of society'. ${ }^{76}$ Most recently, Recommendation CM/Rec (2017)3 continues to permit extended CSMs 'in exceptional circumstances'. ${ }^{77}$ These changes demonstrate increasing attention upon the risk management of dangerous offenders. The Commentary to Recommendation CM/Rec (2017)3 accepts that permitting indeterminate CSMs undermines legal prediction and, thus, 'is contrary to the purpose of developing the offender's autonomy in society' ${ }^{78}$ However, the recommendation does not challenge the legality of indeterminate CSMs. Under Recommendation CM/ $\operatorname{Rec}(2014) 3$, the legality of extended CSMs for dangerous offenders is secured 'by means of regular and independent monitoring, ${ }^{79}$

\section{The proportionality principle}

Although the CFR prohibits disproportionate penalties, the ECtHR does not clearly explain the meaning of 'disproportionate'. Morgenstern and Larrauri (2013, p. 142); Snacken (2006, p. 158) note that the ECtHR loosely interpret 'proportionality'. In its only case involving a choice between incarceration and an alternative measure, the ECtHR did not interfere with the state's

\footnotetext{
${ }_{71}$ Articles 26, 27 and 28, Recommendation CM/Rec(2014)4.

72 Article 49, Charter of Fundamental Rights of the EU.

73 Preamble c and Rule 3, Recommendation No. R(92)16.

${ }^{74}$ Rules 4 and 5, Recommendation No. R(92)16.

75 Appendix 1, Recommendation Rec (2000)22.

${ }^{76}$ Rule 11, Recommendation $\operatorname{Rec}(2003) 22$.

${ }^{77}$ Rule 23, Recommendation CM/Rec (2017)3.

${ }^{78}$ Rule 23, Commentary to Recommendation CM/Rec (2017)3.

${ }^{79}$ Rule 8, Recommendation CM/Rec(2014)3.
} 
decision to impose remand custody. ${ }^{80}$ As this case demonstrates, state authorities are not required to impose only the least-interfering sentence (Snacken 2006, p. 162).

The proportionality principle is also weakened by the considerations of risk management. Under Recommendation No. R(92)16,

'the nature and the duration of community sanctions and measures shall both be in proportion to the seriousness of the offence for which an offender has been sentenced or of which a person is accused and take into account his personal circumstances ${ }^{81}$.

However, under subsequent European instruments, the seriousness of the offence and the offender's culpability are not the only considerations for determining the severity of CSMs. The sentencer should combine the proportionality principle with other factors, including 'the properly assessed risks of reoffending' (Recommendation CM/Rec(2010)1). ${ }^{82}$ Recommendation $\mathrm{CM} / \operatorname{Rec}(2017) 3$ also stipulates that risks must be assessed as well as the individual's needs. $^{83}$

Since the severity of CSMs is determined by multiple factors, sentencers need guidance on the weight to apportion to each in deciding punishment intensity. Recommendation No. $\mathrm{R}$ (92)17 'Concerning Consistency in Sentencing' clearly designates the seriousness of the offence as the primary consideration for sentence severity, 'whatever rationales for sentencing are declared'. ${ }^{84}$ As interpreted by van Zyl Smit and Ashworth (2004, p. 560), this provision means that 'even if the relevant legal framework permits the sentencer to impose a particular sentence for reasons of rehabilitation, deterrence or incapacitation, that sentence must comply with the requirement that it should not be disproportionate'. This interpretation corresponds with the reading of proportionality under the European Commission's Communication (COM/ 2011/0573) 'Towards an EU Criminal Policy'. The communication calls for applying the explicit requirement of proportionality under the CFRights. It also advocates adopting the 'necessity test' with regard to the type and level of sanctions. To be considered proportionate, 'the sanction must be commensurate with the gravity of the conduct and its effects and must not exceed what is necessary to achieve the aim'. ${ }^{85}$ Therefore, for CSMs and for other sentences, the punishment should not be more severe than is necessary, though it is not mandated to be the least interfering. This applies regardless of whether a CSM, based on assessed risks and individual needs, has restrictive or rehabilitative purposes.

\section{Concluding remarks}

CSMs were initially advanced as alternatives to imprisonment, aiming to overcome its shortcomings, show respect for individual liberty, and save costs. However, under more recent related instruments, CSMs are promoted due to their particular characteristics. Traditionally, CSMs are the key domain of rehabilitation. As an integral part of the penal system, they also share the common goal of penal sanctions in seeking to protect the public. European instruments assert interdependence between the two objectives of offender rehabilitation and

\footnotetext{
${ }^{80}$ Bouchet v. France (2001).

${ }^{81}$ Rule 6, Recommendation No. R(92)16.

${ }^{82}$ Rule 5, Recommendation CM/Rec(2010)1.

${ }^{83}$ Rule 22, Recommendation CM/Rec(2017)3.

${ }^{84}$ Rule 4, Recommendation No. R (92)17.

${ }^{85}$ Article 2.2, Communication (COM/2011/0573).
} 
public protection. They consider the indicators related to both objectives as the criteria for effective supervision and control. They also identify the role of cognitive behavioural methods in connecting reducing risk with promoting rehabilitation. However, preoccupations with assessing and managing risk have the potential to increase the punitiveness of CSMs. This risks jeopardising offenders' human rights, especially for those labelled as high risk.

Under European instruments, CSMs are understood to be efficiency-oriented and based on Europe's human rights framework (Morgenstern 2009). Increasing emphasis on offenders' human rights and dignity is recognised to reflect growing resistance to punitiveness in Western Europe (Tonry 2006; Whitman 2003). The European instruments on CSMs require member states to conform with the general legal norms under human rights instruments. The underdevelopment of legal principles in the context of CSMs has been widely recognized. van Zyl Smit (1993, p. 330) observed, just after promulgation of the first CoE recommendation on CSMs, 'It is at the level of an analysis which attempts to derive standards from general legal norms that the various international instruments are most useful'. However, as the specific rules on CSMs are more detailed, particular concern over the risk management of dangerous offenders includes looser interpretations of the legality and proportionality principles. The recommendations on CSMs permit indeterminate sentence duration and include perceived risks and individual needs in the assessment of proportionality. These provisions seem to encourage greater intervention than is strictly necessary (van Zyl Smit et al. 2015). There are two widespread beliefs among European scholars on this topic. First, to retain the European image of resisting punitiveness, the European instruments on CSMs can moderate their penal content by reference to the legal principles of human rights (Morgenstern 2009; Morgenstern and Larrauri 2013; Snacken and McNeill 2012). Second, the instruments can promote firmer and stricter interpretation of legal principles under human rights instruments (Snacken 2006; van Zyl Smit and Ashworth 2004; van Zyl Smit et al. 2015). Interpretations on the legal principles of human rights need to handle the conflict between risk management and protection of offenders' rights. Resolving this conflict is a role for the European instruments. The European instruments should present the European conception of resisting punitiveness, and balance protection of offenders' rights against risk management.

\section{References}

Aebi, M. F., \& Chopin, J. (2013). SPACE II-council of europe annual penal statistics: persons serving non custodial sanctions and measures: survey.

Aebi, M. F., \& Delgrande, N. (2013). SPACE I-council of europe annual penal statistics: prison populations: survey.

Aebi, M. F., Delgrande, N., \& Marguet, Y. (2015). Have community sanctions and measures widened the net of the European criminal justice systems? Punishment \& Society, 17(5), 575-597.

Ashworth, A., \& Horder, J. (2013). Principles of criminal law. Oxford: Oxford University Press.

Baker, E. (2013). The emerging role of the EU as a penal actor. European Penology, 77-111.

Beyens, K. (2016). The new generation of community penalties in Belgium: more is less. Community Punishment: European Perspectives.

Bottoms, A. (2001). Compliance and community penalties. Community penalties: Change and challenges, 87116.

Coyle, A. (2005). Revision of the European Prison Rules. European Prison Rules.

De Vos, H., Gilbert, E., \& Aertsen, I. (2014). Reducing prison population: overview of the legal and policy framework on alternatives to imprisonment at the European level. https:/www.law.kuleuven.be/linc/english/ staff/00085883. 
De Wree, E., Vander Beken, T., \& Vermeulen, G. (2009). The transfer of sentenced persons in Europe: much ado about reintegration. Punishment \& society, 11(1), 111-128.

Dünkel, F. (2017). European penology: The rise and fall of prison population rates in Europe in times of migrant crises and terrorism. European Journal of Criminology, 14(6), 629-653.

Durnescu, I., Enengl, C., \& Grafl, C. (2013). Experiencing supervision. Offender supervision in Europe (pp. 1950). London: Springer.

European Committee on Crime Problems. (2014). Evaluation of the Committee of Ministers recommendations in the field of execution of penal sanctions and measures. (PC-CP (2014) 16 rev 3).

Gallant, K. S. (2009). The Principle of Legality in International and Comparative Criminal Law. Cambridge: Cambridge University Press.

Graebsch, C. M., \& Burkhardt, S.-U. (2014). Ambulant sanctions as an alternative to imprisonment in the European Union. Sofia: Center for the Study of Democracy.

Herzog-Evans, M. (2013). What's in a name: penological and institutional connotations of probation officers' labelling in Europe.p. 121.

Holdsworth, E., \& Hucklesby, A. (2014). Designed for men, but also worn by women: Ella Holdsworth and Anthea Hucklesby point at the gender gap when coping with electronic monitoring. Criminal Justice Matters, 95(1), 14-15.

Jones, R. (2014). The electronic monitoring of offenders: penal moderation or penal excess. Crime, Law and Social Change, 62(4), 475-488.

Lappi-Seppala, T. (2008). Crime prevention and community sanctions in Scandinavia. Helsinki: National Research Institute of Legal Policy.

Long, D., \& Association for the Prevention of Torture. (2002). Guide to jurisprudence on torture and illtreatment: article 3 of the European Convention for the Protection of Human Rights. Geneva: Association for the Prevention of Torture.

Mair, G., \& Canton, R. (2007). Sentencing, community penalties and the role of the Probation Service. Handbook of Probation, 248-291.

Martufi, A., \& Slingeneyer, T. (2017). Soft law instruments of the Council of Europe and community sanctions: criminal policy issues. In A. Bernardi (Ed.), Prison Overcrowding and Alternatives to Detention. Jovene: European Sources and National Legal Systems.

McGuire, J. (2004). Understanding psychology and crime: Perspectives on theory and action. London: McGraw-Hill Education.

McNeill, F. (2013). Community Sanctions and European Penology. In T. Daems, D. van Zyl Smit, \& S. Snacken (Eds.), European penology? London: Bloomsbury.

McNeill, F., \& Beyens, K. (2013). Offender supervision in Europe. London: Springer.

Morgenstern, C. (2009). European initiatives for harmonisation and minimum standards in the field of community sanctions and measures. European Journal of Probation, 1(2), 128-141.

Morgenstern, C. (2016). Consultation about the European Rules on Community Sanctions and Measures. http://www.offendersupervision.eu/wp-content/uploads/2016/01/CSM-Rules-Consultation-Response.pdf.

Morgenstern, C., \& Larrauri, E. (2013). European norms, policy and practice. Offender Supervision in Europe, pp. 125-154. London: Springer.

Morris, N., \& Tonry, M. (1991). Between prison and probation: intermediate punishments in a rational sentencing system. Oxford: Oxford University Press.

Nellis, M. (2015). Standards and ethics in electronic monitoring report. Strasbourg: Council of Europe.

Phelps, M. S. (2013). The paradox of probation: Community supervision in the age of mass incarceration. Law \& Policy, 35(1-2), 51-80.

Robinson, G. (2008). Late-modern rehabilitation The evolution of a penal strategy. Punishment \& Society, 10(4), $429-445$.

Robinson, G. (2013). What counts? Community sanctions and the construction of compliance. What works in offender compliance (pp. 26-43). London: Springer.

Robinson, G. (2016). The Cinderella complex: Punishment, society and community sanctions. Punishment \& Society, 18(1), 95-112.

Robinson, G., \& Crow, I. D. (2009). Offender rehabilitation: Theory, research and practice. Newcastle upon Tyne: Sage.

Robinson, G., \& McNeill, F. (2008). Exploring the dynamics of compliance with community penalties. Theoretical Criminology, 12(4), 431-449.

Robinson, G., \& McNeill, F. (2015). Community punishment: European perspectives. Abingdon: Routledge.

Ruggiero, V., South, N., \& Taylor, I. R. (1998). The new European criminology: crime and social order in Europe. Hove: Psychology Press.

Rutherford, A. (1984). Prisons and the process of justice: the reductionist challenge. London: Heinemann. 
Snacken, S. (2006). A reductionist penal policy and European human rights standards. European Journal on Criminal Policy and Research, 12(2), 143-164.

Snacken, S. (2010). Resisting punitiveness in Europe? Theoretical Criminology, 14(3), 273-292.

Snacken, S., \& McNeill, F. (2012). Scientific recommendations. In D. Flore, S. Bosly, A. Hohon, \& J. Maggio (Eds.), Probation Meaures and Alternative Sanctions in the European Union. Cambridge: Intersentia.

Stefani, G. (2016). Reducing prison population: advanced tools of justice in Europe. http://www.reducingprison. eu/downloads/files/TRAINING PACKAGE.pdf.

Tonry, M. (2006). Purposes and functions of sentencing. Crime and Justice, 34(1), 1-52.

van Zyl Smit, D. (1993). Legal standards and the limits of community sanctions. European Journal of Crime, Criminal Law and Criminal Justice, 1, 309.

van Zyl Smit, D., \& Ashworth, A. (2004). Disproportionate sentences as human rights violations. The Modern Law Review, 67(4), 541-560.

van Zyl Smit, D., Snacken, S., \& Hayes, D. (2015). 'One cannot legislate kindness': Ambiguities in European legal instruments on non-custodial sanctions. Punishment \& Society-International Journal of Penology, 17(1), 3-26. https://doi.org/10.1177/1462474514560186

Vermeulen, G., \& De Bondt, W. (2014). EU justice and home affairs: institutional and policy development. Antwerpen: Maklu.

Whitman, J. Q. (2003). Harsh justice: Criminal punishment and the widening divide between America and Europe. Oxford: Oxford University Press. 